medRxiv preprint doi: https://doi.org/10.1101/2021.12.13.21267753; this version posted December $14,2021$. The copyright holder for this preprint (which was not certified by peer review) is the author/funder, who has granted medRxiv a license to display the preprint in perpetuity.

It is made available under a CC-BY-ND 4.0 International license .

Pulse oximetry in Ugandan primary care

\title{
Hypoxaemia prevalence and management among children and adults presenting to primary care facilities in Uganda: a prospective cohort study.
}

Authors: Hamish R Graham ${ }^{1,2 *}$, Yewande Kamuntu ${ }^{3}$, Jasmine Miller ${ }^{4}$, Anna Barrett ${ }^{1,5}$, Blasio Kunihira ${ }^{3}$, Santa Engol $^{3}$, Lorraine Kabunga ${ }^{3}$, Felix Lam ${ }^{4}$, Charles Olaro ${ }^{6}$, Harriet Ajilong ${ }^{7}$, Freddy Eric Kitutu ${ }^{8,9}$

Affiliations:

1. Melbourne Children's Global Health, MCRI, University of Melbourne, Royal Children's Hospital, Parkville, Victoria, Australia.

2. Department of Paediatrics, University College Hospital, Ibadan, Nigeria.

3. Clinton Health Access Initiative Uganda, Kampala, Uganda.

4. Clinton Health Access Initiative, Boston, United States of America.

5. Nossal Institute of Global Health, University of Melbourne, Parkville, Australia.

6. Director Health Services, Office of the Director of Curative Services, Federal Ministry of Health, Kampala, Uganda.

7. Uganda Paediatric Association, Kampala, Uganda.

8. Department of Pharmacy, Makerere University School of Health Sciences, Kampala, Uganda.

9. Sustainable Pharmaceutical Systems (SPS) unit, Makerere University School of Health Sciences, Kampala, Uganda.

*Corresponding author: Hamish Graham, Centre for International Child Health, Department of Paediatrics, University of Melbourne, Royal Children's Hospital, 50 Flemington Road, Parkville, Victoria 3052, Australia. +61393456262 hamish.graham@rch.org.au

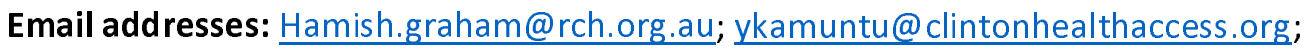

imiller@clintonhealthaccess.org; abarrett@unimelb.edu.au; bkunihira@clintonhealthaccess.org; sengol@clintonhealthaccess.org; lkabunga@clintonhealthaccess.org; flam@clintonHealthAccess.org; olarocharles@gmail.com; harrietajilong@gmail.com; kitutufred@gmail.com

Keywords: pulse oximetry, oxygen, child, pneumonia, primary care, healthcare providers, management, Integrated Management of Childhood IIIness

Running Head: Hypoxaemia in Ugandan primary care

Word count: 4789 
medRxiv preprint doi: https://doi.org/10.1101/2021.12.13.21267753; this version posted December 14, 2021. The copyright holder for this preprint (which was not certified by peer review) is the author/funder, who has granted medRxiv a license to display the preprint in perpetuity.

It is made available under a CC-BY-ND 4.0 International license .

Pulse oximetry in Ugandan primary care

\section{ABSTRACT \\ Introduction}

Hypoxaemia (low blood oxygen) is common among hospitalised patients, increasing risk of death

five-fold and requiring prompt detection and treatment. However, we know little about hypoxaemia prevalence in primary care and the role for pulse oximetry and oxygen therapy. This study assessed the prevalence and management of hypoxaemia at primary care facilities in Uganda.

\section{Methods}

Prospective cohort study in 30 primary care facilities in Uganda, Feb-Apr 2021. Clinical data collectors assessed blood oxygen level $\left(\mathrm{SpO}_{2}\right)$ of all acutely unwell children, adolescents, and adults, and followed up children aged under 15 years with $\mathrm{SpO}_{2}<93 \%$ to determine subsequent care and outcome. Primary outcome: proportion of children under 5 years of age with severe hypoxaemia $\left(\mathrm{SpO}_{2}<90 \%\right)$. Secondary outcomes: severe/moderate hypoxaemia $\left(\mathrm{SpO}_{2} 90-93 \%\right)$ by age/sex/complaint.

\section{Results}

Among children U5, the prevalence of severe hypoxaemia was $1.3 \%$ (95\% $\mathrm{Cl} 0.9$ to 2.1 ); an additional 4.9\% (3.9 to 6.1) had moderate hypoxaemia. Performing pulse oximetry according to World Health Organization guidelines exclusively on children with respiratory complaints would have missed $14 \%$ $(3 / 21)$ of severe hypoxaemia and $11 \%(6 / 55)$ of moderate hypoxaemia. Hypoxaemia prevalence was low among children $5-14$ years ( $0.3 \%$ severe, $1.1 \%$ moderate) and adolescents/adults $15+$ years ( $0.1 \%$ severe, $0.5 \%$ moderate). A minority $(12 / 27,44 \%)$ of severely hypoxaemic patients were referred; 3 (12\%) received oxygen.

\section{Conclusion}

Hypoxaemia is common among acutely unwell children under five years of age presenting to Ugandan primary care facilities. Routine pulse oximetry has potential to improve referral, management and clinical outcomes. Effectiveness, acceptability, and feasibility of pulse oximetry and oxygen therapy for primary care should be investigated in implementation trials. 
medRxiv preprint doi: https://doi.org/10.1101/2021.12.13.21267753; this version posted December 14, 2021. The copyright holder for this preprint (which was not certified by peer review) is the author/funder, who has granted medRxiv a license to display the preprint in perpetuity.

It is made available under a CC-BY-ND 4.0 International license .

Pulse oximetry in Ugandan primary care

\section{KEY QUESTIONS SUMMARY BOX}

\section{What is already known?}

- Hypoxaemia (low blood oxygen levels) is common among children and adults admitted to hospital with severe respiratory illness, increasing their risk of death at least 5-fold and requiring prompt detection and treatment.

- We know little about the prevalence of hypoxaemia in primary care, or whether pulse oximetry would improve decision-making or care for hypoxaemic patients.

\section{What are the new findings?}

- In a Ugandan primary care context, hypoxaemia was common among acutely unwell children under five years of age and most were not referred to hospital for treatment.

- Hypoxaemia was uncommon among older children and adults presenting to Ugandan primary care facilities but prevalence increased with age into older adulthood.

\section{What do the new findings imply?}

- Routine pulse oximetry screening may be warranted for acutely unwell children under five years of age, with a potential to improve referral, management and clinical outcomes.

- Effectiveness, acceptability, and feasibility of pulse oximetry and oxygen therapy for primary care should be investigated in further implementation trials. 
Pulse oximetry in Ugandan primary care

It is made available under a CC-BY-ND 4.0 International license .

\section{BACKGROUND}

Low blood oxygen levels (hypoxaemia) are common among children and adults admitted to hospital and it increases their risk of death 5 -fold and thus requires prompt detection and treatment. ${ }^{1-4}$ Pulse oximetry is a non-invasive and objective method of measuring blood oxygen levels which has greater sensitivity and specificity for hypoxaemia than clinical signs. Healthcare workers (HCWs) use bedside oximeters to detect hypoxaemia and guide patient care - particularly oxygen therapy and other respiratory support. ${ }^{5}$ As such, pulse oximeters are a global standard of care for hypoxaemia management and are regarded as a "priority medical device" by WHO..$^{6-8}$

However, despite WHO primary care guidelines encouraging pulse oximetry screening for young children with respiratory illness, ${ }^{9}$ pulse oximetry availability and use in primary care settings is rare. ${ }^{10-12}$ Previous studies in Africa and Asia-Pacific regions have shown that very few HCWs in primary care facilities have pulse oximeters or are trained to use them, even though it is a simple and acceptable technology. ${ }^{10-15}$ The COVID19 pandemic has brought overdue public urgency and awareness of the longstanding need to strengthen pulse oximetry and oxygen systems in healthcare facilities in low- and middle-income countries (LMICS) - but we have limited data to guide implementation in primary care settings. ${ }^{16-22}$

Limited data suggests that pulse oximetry performed by primary care healthcare workers (HCWs) is feasible and can improve clinical decision-making and referral outcomes. ${ }^{1114}$ Even in settings where oxygen therapy may not be available, pulse oximetry remains useful as it enables HCWs to identify and prioritise severely ill patients for immediate care and referral to more equipped or specialized healthcare facilities where appropriate. In addition to pulse oximetry's role as a diagnostic tool (identifying patients who warrant oxygen therapy) and prognostic tool (identifying severely ill patients at high risk of death), ${ }^{23}$ pulse oximetry can be a communication tool (facilitating information exchange between HCWs and caregivers/patients). ${ }^{24}$

Previous modelling estimates have suggested that increased availability and use of pulse oximetry, accompanied by reliable oxygen delivery systems, could save 148,000 child pneumonia deaths annually in 15 high-mortality countries. ${ }^{25}$ However, these estimates are based on very limited data, including very poor data on the prevalence of hypoxemia in primary care settings. We are aware of only three studies that report hypoxaemia prevalence in primary care settings, finding that $5-15 \%$ of children presenting with pneumonia in the Gambia, Malawi and Ethiopia had severe hypoxaemia $\left(\mathrm{SpO}_{2}<90 \%\right){ }^{1114}$ While these prevalence estimates are lower than those in hospital settings ( $\sim 15-$ $30 \%),{ }^{134}$ they suggest a large number of severely ill patients with hypoxaemia presenting to primary care and not attending hospital. 
medRxiv preprint doi: https://doi.org/10.1101/2021.12.13.21267753; this version posted December 14, 2021. The copyright holder for this preprint (which was not certified by peer review) is the author/funder, who has granted medRxiv a license to display the preprint in perpetuity.

It is made available under a CC-BY-ND 4.0 International license .

Pulse oximetry in Ugandan primary care

Better understanding of hypoxaemia prevalence and current care practices in primary care will enable informed discussion about who should be screened with pulse oximetry (e.g. all patients versus just those with respiratory complaints), where it will be most feasible and cost-effective (e.g. pulse oximetry may not be warranted in small facilities that see very few hypoxaemic patients), and what effects can be expected from introducing pulse oximetry (e.g. numbers of patient referred and burden on larger hospitals). ${ }^{10}$

This study aimed to assess the prevalence and management of hypoxaemia among children and adults presenting to level III health centres (HCIII) facilities in Busoga and North Buganda regions in Uganda.

\section{METHODS}

\section{Study design}

We conducted a prospective cohort study to determine hypoxaemia prevalence and assess its management between February and April 2021 at HCllls in Busoga and North Buganda regions of Uganda that represent the catchment areas of Mubende and Jinja regional referral hospitals (supplemental material).

\section{Study setting}

This study was conducted as part of a partnership between the Ugandan Ministry of Health (MOH) and Clinton Health Access Initiative (CHAl) to improve access to pulse oximetry and oxygen therapy in Uganda. Uganda, a landlocked country in east Africa with 44 million population, has made substantial gains in economic and health development over recent decades. ${ }^{26}$ The leading causes of death in Uganda remain preventable infectious diseases, including pneumonia, malaria, and HIV/AIDS, and neonatal conditions. ${ }^{26}$

The Ugandan $\mathrm{MOH}$ has invested strongly in hospital oxygen services, guided by the National Scale-up of Medical Oxygen Implementation Plan. ${ }^{27}$ The plan describes a clear role for pulse oximetry and oxygen therapy in hospitals, but gives little guidance on the role for pulse oximetry and oxygen therapy at lower level health facilities. ${ }^{27}$

The Uganda health system is organized in tiered structure with five levels and designated service and treatment capacities (Table 1). ${ }^{2829}$ Uganda has approximately 956 HCllls nationally, providing core preventive and curative outpatient services and maternity services to the local population. ${ }^{28}$ In general, patients identified at $\mathrm{HCIII}$ (or $\mathrm{HCll}$ ) as requiring overnight admission are referred to HCIVs or hospitals. ${ }^{27}$ This study focused on government $\mathrm{HCIII}$ facilities as they provide essential frontline health services but are not currently included in plans for pulse oximetry or oxygen service scale up. 
It is made available under a CC-BY-ND 4.0 International license .

Pulse oximetry in Ugandan primary care

Table 1 Overview of the levels of health facilities in Uganda, and typical health services provided. ${ }^{28}$

\begin{tabular}{|l|l|}
\hline Health facility level & Typical services provided \\
\hline $\begin{array}{l}\text { National Referral } \\
\text { Hospital }\end{array}$ & $\begin{array}{l}\text { Comprehensive specialist health services. Health research and teaching. } \\
\text { Located in capital. Number of facilities nationally=1 }\end{array}$ \\
\hline $\begin{array}{l}\text { Regional Referral } \\
\text { Hospital }\end{array}$ & $\begin{array}{l}\text { Specialist health services (e.g., psychiatry, ophthalmology, ENT surgery), } \\
\text { and all general services - inpatient and outpatient. Health research and } \\
\text { teaching. Cover multiple districts. N=14 }\end{array}$ \\
\hline $\begin{array}{l}\text { District General } \\
\text { Hospital }\end{array}$ & $\begin{array}{l}\text { Preventive, promotive, curative maternity, paediatric, medical, surgical, } \\
\text { laboratory and medical imaging services - inpatient and outpatient. In- } \\
\text { service training, limited research. N=52 }\end{array}$ \\
\hline Health Centre IV & $\begin{array}{l}\text { Preventive, promotive, and curative care, including maternity, in-patient } \\
\text { and emergency surgical services. Serves a county. N=180 }\end{array}$ \\
\hline Health Centre III & $\begin{array}{l}\text { Preventive, promotive, and curative care through out-patient services. } \\
\text { Supervises HCll and community outreach activities. N 956 }\end{array}$ \\
\hline Health Centre II & $\begin{array}{l}\text { Basic preventive, promotive and curative care through out-patient and } \\
\text { community outreach activities. }\end{array}$ \\
\hline Village Health Teams & $\begin{array}{l}\text { Facilitate health promotion, service delivery, community participation, } \\
\text { access, and utilization of health services, through community outreach. }\end{array}$ \\
\hline
\end{tabular}

\section{Selection of healthcare facilities}

This study was conducted in 5 districts in North Central/Buganda region and 11 districts in Busoga region, representing the catchment areas of Mubende and Jinja Regional Referral Hospitals.

Study healthcare facilities were arrived at through a multi-stage and purposive sampling approach. We identified $120 \mathrm{HCllls}$ in the target districts (80 in Busoga, 40 in North Central/Buganda), ranging between four and 15 per district. To obtain a representative sample, we entered all the facilities into an Excel spreadsheet (Microsoft Corp, Redmond, WA, US), used the RAND() function to generate random numbers, sorted by size of random number, and selected a pre-specified number of facilities from each district based on each district's population (proportionate stratified sampling). We chose a total of 30 facilities ( $25 \%$ of all facilities) to ensure all districts contributed at least one facility. BK conducted randomisation and selection under supervision (YK, JM) and shared it with the broader team for actioning. After initial randomisation and selection of 30 facilities, we excluded $3 \mathrm{HCllls}$ due to inaccessibility (2 located on an island, 1 located inside an army barracks), replacing them with other HCIlls in their respective district according to the original random number allocation. While HCllls and their patient population vary across Uganda, we expected this to be broadly representative of patients presenting to $\mathrm{HCIIIs} \mathrm{in} \mathrm{Uganda.}{ }^{30}$

\section{Sample size and selection of study population}

We considered all patients presenting to the $\mathrm{HCIII}$ with an acute illness to be eligible for inclusion, expecting most to be children under 5 years of age (U5). We excluded patients visiting the facility for routine pregnancy care, immunisation, child growth monitoring, or other non-acute health 
medRxiv preprint doi: https://doi.org/10.1101/2021.12.13.21267753; this version posted December 14, 2021. The copyright holder for this preprint (which was not certified by peer review) is the author/funder, who has granted medRxiv a license to display the preprint in perpetuity.

It is made available under a CC-BY-ND 4.0 International license .

Pulse oximetry in Ugandan primary care

education or counselling activities. We aimed to capture all eligible patients presenting to participating facilities during the data collection period.

Extrapolating from limited available data we expected U5 hypoxaemia point-prevalence to be around $1 \%,{ }^{1431}$ and estimated that we would need 3,500 children U5 to estimate the pointprevalence of hypoxaemia with a margin of error of $0.5 \%$. Based on admission data from participating facilities, this could be achieved with $70 \mathrm{HClll}$-weeks of observation assuming low refusal to consent rate $(10 \%)$.

We followed up a subgroup of hypoxaemic children $\left(\mathrm{SpO}_{2}<93 \%\right.$ aged $<15$ years) to identify gaps in hypoxaemia management and opportunities for pulse oximetry to improve referral outcomes for this at-risk population.

\section{Data collection}

Trained clinical data collectors were located at each included facility for 4 weeks during operating hours, and were responsible for identification of eligible participants, individual patient/caregiver consent, and survey completion. In practice, this typically meant data collectors were located at the outpatient clinic registration area, approached all patients/caregivers on arrival, requested consent from those eligible, then immediately completed the patient interview and measurement of blood oxygen saturation using pulse oximetry $\left(\mathrm{SpO}_{2}\right)$. Data collectors then met the patient after they had seen the healthcare worker to record diagnosis and treatment recommendations.

Data collectors used a standardised electronic data collection form to collect demographic and clinical data, including details of presenting complaint, signs/symptoms, healthcare worker diagnosis, and treatment recommendations. If $\mathrm{SpO}_{2}$ was less than $93 \%$ and the patient was aged under 15 years, patients/caregivers were also invited to consent to a follow up phone call after 7 days to determine if the patient had attended another health facility, been admitted, or recovered. Data collection forms were pilot tested and revised with input from the local team and academic partners prior to formal data collection commencing. BK and YK supervised data collection activities and $\mathrm{JM}$ reviewed interim data for completeness and consistency. All communication with participants was in the respective local language (Lusoga in Busoga region, Luganda in Buganda region).

Data collectors used handheld pulse oximeters (Biotech Health Care Systems, Indore, India; Edan, San Diego, US) to obtain $\mathrm{SpO}_{2}$ readings, preferentially applying the probe to the toe or finger and attempting readings three times before giving up. Recorded $\mathrm{SpO}_{2}$ readings were documented alongside other vital signs at triage and provided to the treating healthcare worker with 
medRxiv preprint doi: https://doi.org/10.1101/2021.12.13.21267753; this version posted December 14, 2021. The copyright holder for this preprint (which was not certified by peer review) is the author/funder, who has granted medRxiv a license to display the preprint in perpetuity.

It is made available under a CC-BY-ND 4.0 International license .

Pulse oximetry in Ugandan primary care

recommendation for referral for those with $\mathrm{SpO}_{2}$ less than $90 \%$. Project staff provided practical assistance for referral of patients with hypoxaemia when necessary, however final decision lay with the treating healthcare worker and patient/family.

\section{Outcomes}

Our primary outcome was the proportion of acutely unwell children U5 presenting to HCllls with severe hypoxaemia $\left(\mathrm{SpO}_{2}<90 \%\right)^{32}$.

We defined severe hypoxaemia as $\mathrm{SpO}_{2}<90 \%$, indicating a severely unwell cohort warranting oxygen therapy and admission to hospital according to WHO guidelines. ${ }^{92} 33$ We defined moderate hypoxaemia as $\mathrm{SpO}_{2}$ 90-93\%, indicating an unwell cohort with compromised oxygenation warranting consideration for referral, admission and oxygen therapy, particularly for those with additional risk factors (e.g. severe anaemia, heart failure, acute neurological condition, malnutrition). ${ }^{32} 33$ Secondary outcomes included: hypoxaemia by presenting complaint, healthcare worker diagnosis, and age; proportion of hypoxaemic children U15 who were referred, attended hospital, were admitted, and recovered (versus still unwell/died).

\section{Statistical analysis}

We reported hypoxaemia prevalence descriptively by age group and presenting complaint, using point prevalence with $95 \%$ confidence intervals and standard tests of difference in proportions (chisquared or Fisher's exact as appropriate) to compare groups. We classified presenting complaints based on patient/caregiver reported symptoms and diagnosis based on HCW classification. We explored predictors of hypoxaemia using mixed effects logistic regression, including presenting complaint, age and sex as fixed effects and adjusting for clustering at the facility level by including facility as a random effect. We used backwards stepwise selection to identify independent predictive variables for hypoxaemia in each of the major age categories (U5, U15, 5-14 years, 15+ years).

We reported summary statistics on referral and oxygen therapy by age, as recorded by HCWs. We explored predictors of referral by age group using a mixed-effects model, adjusting for hypoxaemia $\left(\mathrm{SpO}_{2}<94 \%\right)$, presenting complaint, age, and sex, and clustering at the facility level.

We mapped the pathway of care, reporting the proportion of children U15 with hypoxaemia $\left(\mathrm{SpO}_{2}<93 \%\right)$ who were referred, attended hospital, were admitted, and recovered (versus still unwell/died). 
medRxiv preprint doi: https://doi.org/10.1101/2021.12.13.21267753; this version posted December 14, 2021. The copyright holder for this preprint (which was not certified by peer review) is the author/funder, who has granted medRxiv a license to display the preprint in perpetuity.

It is made available under a CC-BY-ND 4.0 International license .

Pulse oximetry in Ugandan primary care

\section{Approvals}

We obtained ethical approval for this study from Makerere University School of Health Sciences Research and Ethics Committee (MakSHS REC \#SHSREC Ref No.: 2020-030), and it was cleared and registered by the Uganda National Council of Science and Technology, reference number (HS631ES).

\section{Patient and public involvement}

This study was developed and conducted in partnership with representatives from the Ugandan Ministry of Health (MoH) and Ugandan Paediatric Association, who participated in a technical review group alongside study investigators. Patients, families, or civil society organisations were not involved in the study activities, except in relation to consent and direct participation.

\section{RESULTS}

We approached 7036 potentially eligible participants and successfully enrolled 5813 (83\%). We recorded blood oxygen saturation using pulse oximetry $\left(\mathrm{SpO}_{2}\right)$ on 5788 (99.6\%) participants, including 1561/1575 (99.1\%) children U5 (Figure 1).

\section{Characteristics of participants}

Participants represented all age ranges from newborns to older age (Table 2, supplemental material). Among 1561 children under 5 years, the most reported presenting complaints were fever (77\%), respiratory (74\%), and diarrhoea/vomiting (29\%) (supplemental material). The most common HCW diagnoses were malaria (53\%), acute respiratory infection (ARI, 52\%), and diarrhoeal disease (16\%). The leading presenting complaints and diagnoses among 935 older children aged 5 to 14 years were similar to younger children, with greater preponderance of non-abdominal pain (48\%).

Among those over 15 years of age, the most reported presenting complaints were pain (66\%), fever $(41 \%)$, abdominal (38\%), and respiratory (37\%). The most common HCW diagnoses were ARI (31\%), malaria $(29 \%)$, urinary or genital tract infection $(19 \%)$, or non-diarrhoeal gastrointestinal disease (11\%) (supplemental material).

Participants in Busoga tended to be younger (median 19 versus 22 years) and more female (71\% versus $61 \%$ ) compared to those in North Buganda (supplemental material).

\section{Prevalence of hypoxaemia}

Overall hypoxaemia $\left(\mathrm{SpO}_{2}<94 \%\right)$ prevalence among children and adults presenting with acute illness to $\mathrm{HClll}$ primary care facilities in Uganda was $2.2 \%(95 \% \mathrm{Cl} 1.9$ to 2.7 ) (Table 2). Hypoxaemia burden was greatest among infants under 1 year of age (39/392, 10\%) and children aged 1-4 years (58/1169, 
medRxiv preprint doi: https://doi.org/10.1101/2021.12.13.21267753; this version posted December 14, 2021. The copyright holder for this preprint (which was not certified by peer review) is the author/funder, who has granted medRxiv a license to display the preprint in perpetuity.

Pulse oximetry in Ugandan primary care

It is made available under a CC-BY-ND 4.0 International license .

$5 \%)$ who together accounted for $75 \%$ of hypoxaemia cases. Hypoxaemia prevalence showed a bimodal distribution with age, increasing again in older adulthood (supplemental material).

Table 2 Prevalence of hypoxaemia among acutely unwell children, adolescents and adults presenting to primary care (HCIII) facilities in Uganda, Feb-Apr 2021

\begin{tabular}{|c|c|c|c|c|c|c|c|c|c|}
\hline \multirow{3}{*}{ Neonate } & \multirow{3}{*}{$\begin{array}{c}\text { Total } \\
16\end{array}$} & \multicolumn{4}{|c|}{$\begin{array}{c}\text { Severe hypoxaemia } \\
\left(\mathrm{SpO}_{2}<90 \%\right) \\
\end{array}$} & \multicolumn{4}{|c|}{$\begin{array}{c}\text { Moderate hypoxaemia } \\
\left(\mathrm{SpO}_{2} 90-93 \%\right)\end{array}$} \\
\hline & & \multirow{2}{*}{$\frac{\mathbf{N}}{0}$} & \multirow{2}{*}{$\frac{\text { prevalence }}{\text {. }}$} & \multicolumn{2}{|c|}{$95 \% \mathrm{CI}$} & \multirow{2}{*}{$\frac{\mathbf{N}}{4}$} & \multirow{2}{*}{$\frac{\text { prevalence }}{25.0 \%}$} & \multicolumn{2}{|c|}{$95 \% \mathrm{CI}$} \\
\hline & & & & . & . & & & $8.9 \%$ & $53.3 \%$ \\
\hline 1-11 months & 376 & 8 & $2.1 \%$ & $1.1 \%$ & $4.2 \%$ & 27 & $7.2 \%$ & $5.0 \%$ & $10.3 \%$ \\
\hline 1-4 years & 1,169 & 13 & $1.1 \%$ & $0.6 \%$ & $1.9 \%$ & 45 & $3.8 \%$ & $2.9 \%$ & $5.1 \%$ \\
\hline 5-9 years & 633 & 3 & $0.5 \%$ & $0.2 \%$ & $1.5 \%$ & 5 & $0.8 \%$ & $0.3 \%$ & $1.9 \%$ \\
\hline 10-14 years & 302 & 0 & . & . & . & 5 & $1.7 \%$ & $0.7 \%$ & $3.9 \%$ \\
\hline 15-24 years & 1,088 & 0 & . & . & . & 3 & $0.3 \%$ & $0.1 \%$ & $0.9 \%$ \\
\hline 25-49 years & 1,602 & 1 & $0.1 \%$ & $0.0 \%$ & $0.4 \%$ & 7 & $0.4 \%$ & $0.2 \%$ & $0.9 \%$ \\
\hline $50+$ years & 594 & 2 & $0.3 \%$ & $0.1 \%$ & $1.3 \%$ & 7 & $1.2 \%$ & $0.6 \%$ & $2.5 \%$ \\
\hline Total & 5780 & 27 & $0.5 \%$ & $0.3 \%$ & $0.7 \%$ & 103 & $1.8 \%$ & $1.5 \%$ & $2.2 \%$ \\
\hline Girls (<5 years) & 790 & 14 & $1.8 \%$ & $1.1 \%$ & $3.0 \%$ & 38 & $4.8 \%$ & $3.5 \%$ & $6.5 \%$ \\
\hline Boys (<5 years) & 771 & 7 & $0.9 \%$ & $0.4 \%$ & $1.9 \%$ & 38 & $4.9 \%$ & $3.6 \%$ & $6.7 \%$ \\
\hline Girls (5-14 years) & 568 & 1 & $0.2 \%$ & $0.0 \%$ & $1.2 \%$ & 4 & $0.7 \%$ & $0.3 \%$ & $1.9 \%$ \\
\hline Boys (5-14 years) & 367 & 2 & $0.5 \%$ & $0.1 \%$ & $2.2 \%$ & 6 & $1.6 \%$ & $0.7 \%$ & $3.6 \%$ \\
\hline Women ( $\geq 15$ years) & 2,561 & 1 & $0.0 \%$ & $0.0 \%$ & $0.3 \%$ & 14 & $0.5 \%$ & $0.3 \%$ & $0.9 \%$ \\
\hline Men $(\geq 15$ years $)$ & 723 & 2 & $0.3 \%$ & $0.1 \%$ & $1.1 \%$ & 3 & $0.4 \%$ & $0.1 \%$ & $1.3 \%$ \\
\hline Busoga & 4,120 & 20 & $0.5 \%$ & $0.3 \%$ & $0.7 \%$ & 86 & $2.1 \%$ & $1.7 \%$ & $2.6 \%$ \\
\hline North Central & 1,660 & 7 & $0.4 \%$ & $0.2 \%$ & $0.9 \%$ & 17 & $1.0 \%$ & $0.6 \%$ & $1.6 \%$ \\
\hline
\end{tabular}

U5 YEARS BY PRESENTING COMPLAINT

\begin{tabular}{|l|c|c|ccc|c|ccc|}
\hline Resp OR fever & 1,478 & 21 & $1.4 \%$ & $0.9 \%$ & $2.2 \%$ & 75 & $5.1 \%$ & $4.1 \%$ & $6.3 \%$ \\
\hline Respiratory & 1,158 & 18 & $1.6 \%$ & $1.0 \%$ & $2.5 \%$ & 67 & $5.8 \%$ & $4.6 \%$ & $7.3 \%$ \\
\hline Fever & 1,208 & 15 & $1.2 \%$ & $0.7 \%$ & $2.1 \%$ & 59 & $4.9 \%$ & $3.8 \%$ & $6.3 \%$ \\
\hline Diarrhoea/Vomit & 459 & 5 & $1.1 \%$ & $0.5 \%$ & $2.6 \%$ & 17 & $3.7 \%$ & $2.3 \%$ & $5.9 \%$ \\
\hline Malaria & 825 & 10 & $1.2 \%$ & $0.7 \%$ & $2.2 \%$ & 34 & $4.1 \%$ & $3.0 \%$ & $5.7 \%$ \\
\hline ARI & 811 & 13 & $1.6 \%$ & $0.9 \%$ & $2.7 \%$ & 53 & $6.5 \%$ & $5.0 \%$ & $8.5 \%$ \\
\hline \multicolumn{1}{|c|}{ 'Pneumonia" } & 133 & 7 & $5.3 \%$ & $2.5 \%$ & $10.7 \%$ & 18 & $13.5 \%$ & $8.7 \%$ & $20.5 \%$ \\
\hline Diarrhoeal disease & 243 & 3 & $1.2 \%$ & $0.4 \%$ & $3.8 \%$ & 10 & $4.1 \%$ & $2.2 \%$ & $7.5 \%$ \\
\hline Sepsis & 41 & 0 &. &. &. & 7 & $17.1 \%$ & $8.2 \%$ & $32.3 \%$ \\
\hline Total U5 & $\mathbf{1 , 5 6 1}$ & $\mathbf{2 1}$ & $\mathbf{1 . 3 \%}$ & $\mathbf{0 . 9 \%}$ & $\mathbf{2 . 1 \%}$ & $\mathbf{7 6}$ & $\mathbf{4 . 9 \%}$ & $\mathbf{3 . 9 \%}$ & $\mathbf{6 . 1 \%}$ \\
\hline
\end{tabular}

Notes: U5 = under 5 years of age; presenting complaints reported by patient or caregiver; clinician diagnosis recorded by treating healthcare worker; ARI = acute respiratory infection; Sepsis includes bacteraemia and septic wound. 
medRxiv preprint doi: https://doi.org/10.1101/2021.12.13.21267753; this version posted December 14, 2021. The copyright holder for this preprint (which was not certified by peer review) is the author/funder, who has granted medRxiv a license to display the preprint in perpetuity.

It is made available under a CC-BY-ND 4.0 International license .

Pulse oximetry in Ugandan primary care

\section{Children aged $<5$ years}

Among children $\mathrm{U} 5$, the prevalence of severe hypoxaemia $\left(\mathrm{SpO}_{2}<90 \%\right)$ was $1.3 \%$ ( $95 \% \mathrm{Cl} 0.9$ to 2.1 ) and $4.9 \%$ (3.9 to 6.1) had moderate hypoxaemia $\left(\mathrm{SpO}_{2} 90-93 \%\right)$ (Table 2 ).

Hypoxaemia prevalence was highest among those presenting with respiratory complaints $(7.3 \%, 6.0$ to 9.0) or fever (6.1\%, 4.9 to 7.6) (Table 2, supplemental material). Hypoxaemia was uncommon among those without fever or respiratory complaints (1/83, 1.2\%). Performing pulse oximetry according to $\mathrm{WHO} \mathrm{IMCl}$ guidelines exclusively on children $\mathrm{U} 5$ with respiratory tract complaints would have captured $86 \%(18 / 21)$ of severe hypoxaemia and $88 \%(67 / 76,88 \%)$ of moderate hypoxaemia among children U5.

Hypoxaemia prevalence was most common among children diagnosed with ARI (8.1\%, 6.4 to 10.2$)$, malaria ( $5.3 \%, 4.0$ to 7.1$)$, or sepsis $(17.1 \%, 8.2$ to 32.3$)$, and particularly high for those diagnosed with pneumonia (18.8\%, 13.0 to 26.4 )(Figure 2, supplemental material).

\section{Children aged $5-14$ years}

Among children aged 5-14 years, the prevalence of severe hypoxaemia was $0.3 \%$ (0.1 to 1.0 ) and $1.1 \%$ ( 0.6 to 2.0 ) had moderate hypoxaemia(Table 2 ). Hypoxaemia was most common among older children presenting with respiratory symptoms $(2.2 \%)$, fevers $(1.8 \%)$, or pain $(1.6 \%)$. ARI and malaria accounted for $85 \%(11 / 13)$ of hypoxaemia cases (supplemental material).

\section{Adolescents and adults $\geq 15$ years}

Compared to children, hypoxaemia prevalence among adolescents and adults aged over 15 years was lower and less predicted by presenting complaint or diagnosis. While, hypoxaemia was most common among those presenting with respiratory complaints $(0.8 \%, 0.4$ to 1.4$)$ or fever $(0.5 \%, 0.3$ to 1.1$)$, one-third $(7 / 20,35 \%)$ of adolescents and adults with hypoxaemia did not have either fever or respiratory complaints (Table $\mathbf{2}$, supplemental material).

\section{Predictors of hypoxaemia}

Among children U5 years, adjusted analysis identified hypoxaemia to be associated with age (aOR $0.66,95 \% \mathrm{Cl} 0.54$ to 0.79 ) and the presence of respiratory complaints (aOR 2.46, 1.30-4.66) with similar results for those 5-14 years (supplemental material). For those 15 years and over, age was the only variable independently associated with hypoxaemia, with older age associated with higher risk of hypoxaemia (aOR 1.05, 1.02-1.07).

\section{Referral and management}

Overall, $32(0.55 \%)$ participants were referred by HCWs to a higher-level facility, with minimal variation across age groups but some variation between North Central and Busoga region $1.1 \%$ 
medRxiv preprint doi: https://doi.org/10.1101/2021.12.13.21267753; this version posted December 14, 2021. The copyright holder for this preprint (which was not certified by peer review) is the author/funder, who has granted medRxiv a license to display the preprint in perpetuity.

It is made available under a CC-BY-ND 4.0 International license .

Pulse oximetry in Ugandan primary care

versus $0.3 \%, \mathrm{P}=0.001)$. While one-third of those referred $(12 / 32,38 \%)$ had $\mathrm{SpO}_{2}<90 \%$, less than half of those with severe hypoxaemia $\left(\mathrm{SpO}_{2}<90 \%\right)$ were referred $(12 / 27,44 \%)$.

Oxygen was rarely available and was provided to only 3 patients $(0.06 \%)$. A severely hypoxaemic $\left(\mathrm{SpO}_{2} 61 \%\right)$ infant with febrile respiratory illness was the only patient with $\mathrm{SpO}_{2}<90 \%$ who received oxygen therapy $(1 / 27,3.7 \%)$. Two other patients with $\mathrm{SpO}_{2} 93 \%$ and $98 \%$ were recorded as receiving oxygen.

\section{Follow up of children with hypoxaemia: hospital attendance, admission, outcomes}

\section{Hypoxaemia $\mathrm{SpO}_{2} \leq 94 \%$}

We followed up 87 children aged under 15 years with $\mathrm{SpO}_{2}<93 \%$ and successfully obtained referral and outcome data for 61 (70\%) children (including 56 under 5 years of age) (Figure 3). Of those with complete data, $6(10 \%)$ had been referred to a larger facility at the initial clinic visit, $10(16 \%)$ had sought care at another facility, $6(10 \%)$ were admitted overnight, and 44 (72\%) had fully recovered at day 7 follow up. Of the 51 who did not attend another facility, the most commonly cited reason was that the caregiver thought it was unnecessary $(42,82 \%)$, with other reasons including cost $(8,16 \%)$, and distance or lack of transport $(3,6 \%)$.

Most children who had "not fully recovered" by day 7 had neither been referred by HCW nor sought care elsewhere $(12 / 17,71 \%)$. The only recorded death was of a severely hypoxaemic infant with pneumonia who was treated with appropriate antibiotics and referred (but not given oxygen) who died soon after arriving at the referral facility.

\section{Severe hypoxaemia $\mathrm{SpO}_{2} \leq 90 \%$}

Despite study staff recommending referral for all 24 children with severe hypoxaemia $\left(\mathrm{SpO}_{2}<90 \%\right)$ a minority $(10,42 \%)$ were referred by the treating healthcare worker (supplemental material). Healthcare workers gave various reasons for not referring including: they felt confident managing the child locally (4, 29\%); caregiver declined referral or was worried about cost (3,21\%); patient had already left facility $(2,14 \%)$; unknown (5, 38\%). While overnight admission for children was not routinely provided at participating facilities, at least four severely hypoxaemic children were observed for a period before being discharged home, including one who received oxygen therapy. Of severely hypoxaemic children who were referred, all (6/6) attended another facility, 67\% (4/6) were admitted ( 1 died prior to admission), and half (3/6) had fully recovered on day 7 . Of severely hypoxaemic children who were not referred, $20 \%(2 / 10)$ subsequently sought care, $10 \%(1 / 10)$ were admitted, and $90 \%(9 / 10)$ had fully recovered by day 7 (supplemental material). 
medRxiv preprint doi: https://doi.org/10.1101/2021.12.13.21267753; this version posted December 14, 2021. The copyright holder for this preprint (which was not certified by peer review) is the author/funder, who has granted medRxiv a license to display the preprint in perpetuity.

Pulse oximetry in Ugandan primary care

It is made available under a CC-BY-ND 4.0 International license .

\section{DISCUSSION}

To our knowledge this is the first study reporting hypoxaemia prevalence among children, adolescents, and adults presenting to primary care facilities, providing unique data on hypoxaemia prevalence, referral patterns, and outcomes.

Our findings suggest that, while overall prevalence of hypoxaemia in Ugandan primary care facilities is low, young children are a key risk group for whom routine pulse oximetry assessment may improve identification and management of hypoxaemia. Current referral practices are missing a significant number of severely unwell children with hypoxaemia and pulse oximetry may be a useful tool in helping HCWs prioritise patients and facilitate referral.

\section{Hypoxaemia in children}

\section{All presentations}

We found that moderate or severe hypoxaemia was relatively common among children U5 presenting to primary care facilities $\left(1.3 \%\right.$ had $\mathrm{SpO}_{2}<90 \%$ and $4.9 \%$ had $\left.\mathrm{SpO}_{2} 90-93 \%\right)$ but uncommon among older children aged $5-14$ years $\left(0.3 \% \mathrm{SpO}_{2}<90 \%, 1.4 \% \mathrm{SpO}_{2} 90-93 \%\right)$. Assuming similar prevalence nationally and throughout the year, this equates to $>40,000$ children U5 presenting to HCIIIs in Uganda with hypoxaemia annually (including $\sim 8,700$ with severe hypoxaemia) - most of whom are not currently identified, treated, or referred.

We found no published studies that have reported hypoxaemia prevalence among general child presentations to primary care settings. Unpublished interim data from primary care facilities in Malawi reported similar results among acutely unwell children U5 $\left(0.6 \% \mathrm{SpO}_{2}<90 \%, 5.4 \% \mathrm{SpO}_{2} 90-\right.$ 93\%) (personal correspondence Helena Hildenwall 11 August 2021) (Table 3).

Table 3 Comparison of U5 hypoxaemia prevalence findings with other studies

\begin{tabular}{|l|c|c|c|}
\hline Study & $\mathbf{N}$ & $\begin{array}{c}\text { Severe hypoxaemia } \\
\left(\mathrm{SpO}_{2}<90 \%\right)\end{array}$ & $\begin{array}{c}\text { Moderate hypoxaemia } \\
\left(\mathrm{SpO}_{2} 90-93 \%\right)\end{array}$ \\
\hline \multicolumn{3}{|c|}{ Children U5 - all comers } \\
\hline Uganda HCIII & 1551 & $1.3 \%$ & $4.9 \%$ \\
\hline Malawi (unpublished) - Mchinji district & $\sim 3000$ & $0.6 \%$ & $5.4 \%$ \\
\hline \multicolumn{2}{|c|}{ Children U5 - pneumonia / respiratory illness } \\
\hline Uganda HCIII - "respiratory complaints" & 1151 & $1.6 \%$ & $5.8 \%$ \\
\hline Uganda HCIII - "pneumonia diagnosis" & 133 & $5.3 \%$ & $13.5 \%$ \\
\hline The Gambia (1991)31- "pneumonia" rural & 1033 & $10.2 \%$ & - \\
\hline Malawi (2016) - "pneumonia" rural & 13266 & $4.9 \%$ & - \\
\hline Ethiopia (2020) - "pneumonia/severe" & 928 & $14.5 \%$ & $10.2 \%$ \\
\hline $\begin{array}{l}\text { Nigeria urban (unpublished) - } \\
\text { "pneumonia/severe", }\end{array}$ & 870 & $7.5 \%$ & $7.0 \%$ \\
\hline $\begin{array}{l}\text { Bangladesh (unpublished) - } \\
\text { "pneumonia/severe" }\end{array}$ & 9619 & $1.9 \%$ & \\
\hline
\end{tabular}

Unpublished data obtained from personal correspondence Helena Hildenwall (Malawi), Carina King (Nigeria), Eric McCollum (Bangladesh), August/September 2021. 
medRxiv preprint doi: https://doi.org/10.1101/2021.12.13.21267753; this version posted December 14, 2021. The copyright holder for this preprint (which was not certified by peer review) is the author/funder, who has granted medRxiv a license to display the preprint in perpetuity.

It is made available under a CC-BY-ND 4.0 International license .

Pulse oximetry in Ugandan primary care

\section{Pneumonia}

We found that $1.6 \%$ of children U5 presenting to participating Ugandan health facilities with respiratory complaints had $\mathrm{SpO}_{2}<90 \%$ and an additional $5.8 \%$ had $\mathrm{SpO}_{2} 90-93 \%$. When restricted to those with specific diagnosis of pneumonia or severe pneumonia, 5.3\% had $\mathrm{SpO}_{2}<90 \%$ and an additional $13.5 \%$ had $\mathrm{SpO}_{2}$ 90-93\%. However, the relatively low pneumonia diagnosis case numbers suggest significant under-diagnosis.

A systematic review of hypoxaemia prevalence reported that around $13 \%$ of children aged under 5 years with severe or very severe pneumonia had hypoxaemia (typically defined as $\mathrm{SpO}_{2}<90 \%$ ). ${ }^{3}$ However, most included studies were in hospital settings. A single primary care study from the early 1990 s found $10.2 \%$ (105/1033) of children with pneumonia presenting to health centres or mobile clinics in the Gambia had severe hypoxaemia (Table 3). ${ }^{31}$ More recent data from Malawi reported that $4.9 \%(652 / 13266)$ of children U5 with pneumonia presenting to community or village clinics had $\mathrm{SpO}_{2}<90 \%$ and an additional $8.8 \%(1170 / 13266)$ had $\mathrm{SpO}_{2} 90-92 \%,{ }^{14}$ with similar estimates from unpublished data from rural Bangladesh and urban Nigeria (Table 3) (personal correspondence Carina King 1 September 2021 and Eric McCollum 1 September 2021).

Differences in these hypoxaemia estimates likely represent both variance in pneumonia case definition and contextual factors such as access to and thresholds for seeking care, prevalence of malnutrition and other risk factors for severe disease, and level of service provided the participating primary care facility.

\section{$\underline{\text { Referral patterns }}$}

We observed relatively low rate of referral for young children with hypoxaemia even though study staff recommended referral to the treating HCW and offered referral support. Previous studies have shown a markedly increased risk of death among children who present with hypoxaemia, ${ }^{234} 35$ including in primary care settings. This risk of death is proportional to the degree of hypoxaemia with higher risk of death even among children with moderate hypoxaemia $\left(\mathrm{SpO}_{2} 90-93 \%\right){ }^{1}$

Referral decision-making is a complex process involving HCW and caregiver judgement of how unwell the child is and the cost-benefit of going to hospital and decisions are influenced by sociocultural and structural factors. ${ }^{36}$ This was reflected in the feedback from HCWs and caregivers, for whom multiple barriers to referral existed even with the offer of referral assistance. Our study was not powered to detect differences in mortality, but it is concerning that a significant proportion of children who were not referred were subsequently taken to a referral facility by caregivers, required admission, and had not fully recovered by day 7 . 
medRxiv preprint doi: https://doi.org/10.1101/2021.12.13.21267753; this version posted December 14, 2021. The copyright holder for this preprint (which was not certified by peer review) is the author/funder, who has granted medRxiv a license to display the preprint in perpetuity.

It is made available under a CC-BY-ND 4.0 International license .

Pulse oximetry in Ugandan primary care

Importantly, treating HCWs had not received training on pulse oximetry or hypoxaemia, most had never seen a pulse oximeter, and hypoxaemia was not part of their standard IMCI guidelines.

Previous studies suggest that if these HCWs were provided with equipment, training, and modification of their treatment guidelines they could quickly become skilled at using oximetry and using it to improve decision-making. ${ }^{10141537}$ Similarly, caregivers in our study were not familiar with oximetry and it was not used to explain or persuade. Hospital experience from Nigeria suggests that caregivers respond positively to oximetry and may be more likely to follow HCW recommendations if hypoxaemia is explained. ${ }^{24}$ Nonetheless, barriers to hospital referral are many and this may also be an argument to not only introduce pulse oximetry but to also make oxygen and admission services available more locally.

\section{Hypoxaemia in adolescents and adults}

The COVID-19 pandemic has highlighted the risk of hypoxaemia for adults and stimulated the introduction of pulse oximetry into hospitals, primary health and community care in many countries. ${ }^{38-40}$ However we have not seen any data on hypoxaemia among adults presenting to primary care in LMICs for either respiratory or non-respiratory conditions.

We found that hypoxaemia is uncommon among acutely unwell adults presenting to primary care facilities in Uganda (0.1\% had $\mathrm{SpO}_{2}<90 \%$ and $0.5 \%$ had $\mathrm{SpO}_{2}$ 90-93\%). However, hypoxaemia was more common among adolescents and adults with respiratory complaints $\left(0.2 \%\right.$ had $\mathrm{SpO}_{2}<90 \%$ and $0.6 \%$ had $\left.\mathrm{SpO}_{2} 90-93 \%\right)$ and older adults $50+$ years $\left(0.3 \%\right.$ had $\mathrm{SpO}_{2}<90 \%$ and $1.2 \%$ had $\mathrm{SpO}_{2} 90-93 \%$ ).

\section{Implications for referral and treatment guidelines}

Current WHO guidelines recommend pulse oximetry "if available" for children U5 with respiratory complaints and recommend admission and oxygen therapy for those with $\mathrm{SpO}_{2}<90 \% .{ }^{93}{ }^{41}$ Existing guidelines recommend targeting of higher saturation levels $\left(\mathrm{SpO}_{2}>94 \%\right)$ for those with particular risk (e.g. severe anaemia, heart failure, acute neurological condition), ${ }^{32} 33$ and recognise that lower saturations may be better tolerated by people living at high-altitude who have physiologically adapted to low oxygen environments. ${ }^{42}$

However, saturation thresholds for administering oxygen therapy are different to thresholds for clinical concern and guidelines developed for hospital settings do not necessarily translate directly to primary care settings. In view of the limited data about hypoxaemia and pulse oximetry in primary care settings we cannot make strong recommendations regarding pulse oximetry in primary care. However, we have identified four key areas that warrant consideration and further exploration. 
First, routine pulse oximetry is likely to detect severe illness in children and adults presenting to primary care that would otherwise go unrecognised. While hypoxaemia is challenging to detect using clinical features across all age groups, ${ }^{1843-45}$ the high prevalence of hypoxaemia in children U5 highlights this as a priority cohort for routine pulse oximetry screening in primary care. Current IMCI guidelines suggest pulse oximetry for children U5 presenting with respiratory complaints. ${ }^{9}$ Our data suggests that this approach would require screening of three-quarters of children and would miss $10 \%$ of children with severe hypoxaemia. A simpler approach may be to screen all acutely unwell children U5 and encourage oximetry use for older children and adults with signs of respiratory disease or severe illness.

Second, adoption and sustained use of pulse oximetry relies on HCWs being convinced that it provides a benefit. ${ }^{24}$ Perceived benefit is influenced by prevalence of hypoxaemia (how frequently they will detect an abnormality that is clinically relevant) but also by whether hypoxaemia detection leads to practice and outcome change. Our study strengthens evidence showing that the inclusion of hypoxaemia in referral guidelines could change the number of children U5 identified for referral. ${ }^{14}$ However, whether this translates to actual change in referral practices and behaviours needs further evaluation.

Third, the hypoxaemia threshold for clinical concern and referral should probably be more inclusive than the threshold for providing oxygen therapy. In the absence of specific data, current WHO primary care guidelines for referral use the same threshold as general hospital guidelines for administering oxygen therapy $\left(\mathrm{SpO}_{2}<90 \%\right) .{ }^{93}$ However, the clear association between moderate hypoxaemia and poor clinical outcomes suggests that even moderate hypoxaemia $\left(\mathrm{SpO}_{2} 90-93 \%\right)$ should be an indication for strong clinical concern and consideration for referral and admission for period of observation - particularly in the presence of comorbid conditions - or at least prompt more frequent review.

Fourth, while HCWs can quickly learn to use pulse oximeters effectively, practical challenges exist in translating this into sustained performance. Pulse oximetry is a simple practice but we and others have seen variability in the proportion of failed or implausible readings as new users develop competence. ${ }^{1437} 46 \mathrm{HCWs}$ need to build confidence and skill in performing oximetry and interpreting results. Performance could be negatively impacted by infrequent practice, lack of perceived benefit (e.g. unable to treat or refer even after detection), lack of technical support resulting in repeated failure, high frequency of false positives reducing trust, lack of authoritative guidance in policy and procedures, negative opinions or critique from supervisors. ${ }^{24}$ 
medRxiv preprint doi: https://doi.org/10.1101/2021.12.13.21267753; this version posted December 14, 2021. The copyright holder for this preprint (which was not certified by peer review) is the author/funder, who has granted medRxiv a license to display the preprint in perpetuity.

It is made available under a CC-BY-ND 4.0 International license .

Pulse oximetry in Ugandan primary care

\section{Limitations}

Our study involved 30 primary health care facilities across two regions in Uganda providing a representative sample and employed prospective data collection methods to maximise the quality of data. We had very high consent and completion rates, and very high success rates for pulse oximetry. However, we had high rates of drop-out (30\%) from post-visit follow up despite multiple attempts to contact consented families by phone. Sensitivity analysis showed no difference in reported care-seeking or clinical status on day 7 between those who were contacted on first, second, or third attempt, suggesting non-response was random. But it is possible that those who were not able to be contacted differed in risk (e.g. socioeconomic status) or outcome profiles and follow-up data should be interpreted with caution.

To obtain data from many facilities we restricted the period of data collection to 4 weeks at each facility, with data collectors moving between facilities. Data collection occurred over the warm, dry season months that are typically low-incidence for ARI and malaria and may underestimate the case numbers and hypoxaemia prevalence in other seasons. ${ }^{47}$ At the time of this study (February to April 2021), Uganda was experiencing the COVID-19 pandemic, with data collection commencing shortly after a second major wave of infections had subsided and restrictions loosened in January 2021. While we observed similar service activity compared to previous years, changes in care-seeking, hygiene and social behaviour may have influenced participant characteristics and reduced the prevalence of ARI.

Pulse oximeter accuracy depends on the quality of the oximeter probe, internal computer/algorithm, and how it is used. ${ }^{48}$ In lab conditions, pulse oximeters provide oxygen saturations with accuracy of $+/-2-3 \%$ and can be less accurate in patients with dark skin, low perfusion states, very low saturations, and those who are moving (e.g. crying child). ${ }^{39} 49$ Previous studies have raised concerns about the quality of some low-cost oximeters, particularly finger-tip oximeters. ${ }^{48-51}$ We used handheld oximeters that met global quality standards and did not conduct any independent validation of results.

\section{Interpretation and generalisability}

Our study represents hypoxaemia prevalence and practices among primary care ( $\mathrm{HCll}$ ) facilities in two regions of Uganda. While the specific case-mix and referral findings must be understood in context, the broader findings regarding hypoxaemia burden and role for pulse oximetry are generalisable to primary care settings across the region. In the context of increasing pulse oximeter affordability, availability, and HCW acceptance, data from our observation study can inform policy, programming, and future implementation trials. Important future research questions should assess: 
medRxiv preprint doi: https://doi.org/10.1101/2021.12.13.21267753; this version posted December 14, 2021. The copyright holder for this preprint (which was not certified by peer review) is the author/funder, who has granted medRxiv a license to display the preprint in perpetuity.

It is made available under a CC-BY-ND 4.0 International license .

Pulse oximetry in Ugandan primary care

effects of pulse oximetry on practice change and clinical outcomes; alternate cut-points for decisionmaking (e.g. $\mathrm{SpO}_{2} 94 \%$ versus $90 \%$ ); alternate treatment options for those with hypoxaemia (e.g. referral versus day-care); time and resource cost; and contextual influences on adoption and impact.

\section{CONCLUSIONS}

Hypoxaemia is common among acutely unwell children U5 presenting to Ugandan primary care facilities, and routine pulse oximetry assessment has the potential to improve referral, management and clinical outcomes. Effectiveness, acceptability, and feasibility of pulse oximetry for primary care should be investigated in implementation trials. 
medRxiv preprint doi: https://doi.org/10.1101/2021.12.13.21267753; this version posted December 14, 2021. The copyright holder for this preprint (which was not certified by peer review) is the author/funder, who has granted medRxiv a license to display the preprint in perpetuity.

It is made available under a CC-BY-ND 4.0 International license .

Pulse oximetry in Ugandan primary care

\section{Additional statements}

Competing Interests: HG is an advisor to the Lifebox Foundation, UNICEF, and Unitaid on pulse oximetry. YK, JM, BK, SE, LK, FL are employed by CHAl who are implementing the oxygen program in Uganda. CO works for the Federal Ministry of Health which provides funding and oversight for health facilities.

Funding: This project was funded by a grant from the Bill and Melinda Gates Foundation (BMGF) INV-001132 and ELMA Philanthropies. Any views or opinions presented are solely those of the author and do not necessarily represent those of BMGF or ELMA, unless otherwise specifically stated. The funder was not involved in the writing of this manuscript or decision for publication.

Authors' contributions: HG, FL, JM, YK, BK conceived of the study. HG, FL, JM, BK initiated the study design, FK, CO, HA revised the protocol, and YK, BK, SE led data collection and implementation. Data analysis was conducted by $A B$ assisted by JM, HG, FL, BK. The manuscript was drafted by HG, with input from $\mathrm{FK}, \mathrm{FL}, \mathrm{JM}, \mathrm{AB}, \mathrm{YK}$, and $\mathrm{BK}$. All authors contributed to revisions and approved the final manuscript.

Ethics approval: This study has received ethical approval from the Research Ethics Committee at: Makerere University College of Health Sciences (\#SHSREC Ref No.: 2020-030) and clearance and registration by the Uganda National Council of Science and Technology, reference number (HS631ES).

Data availability: All relevant data for this study is included in the manuscript and supplemental files. 
medRxiv preprint doi: https://doi.org/10.1101/2021.12.13.21267753; this version posted December 14, 2021. The copyright holder for this preprint (which was not certified by peer review) is the author/funder, who has granted medRxiv a license to display the preprint in perpetuity.

It is made available under a CC-BY-ND 4.0 International license .

Pulse oximetry in Ugandan primary care

\section{Figures}

Figure 1 Participant flow chart

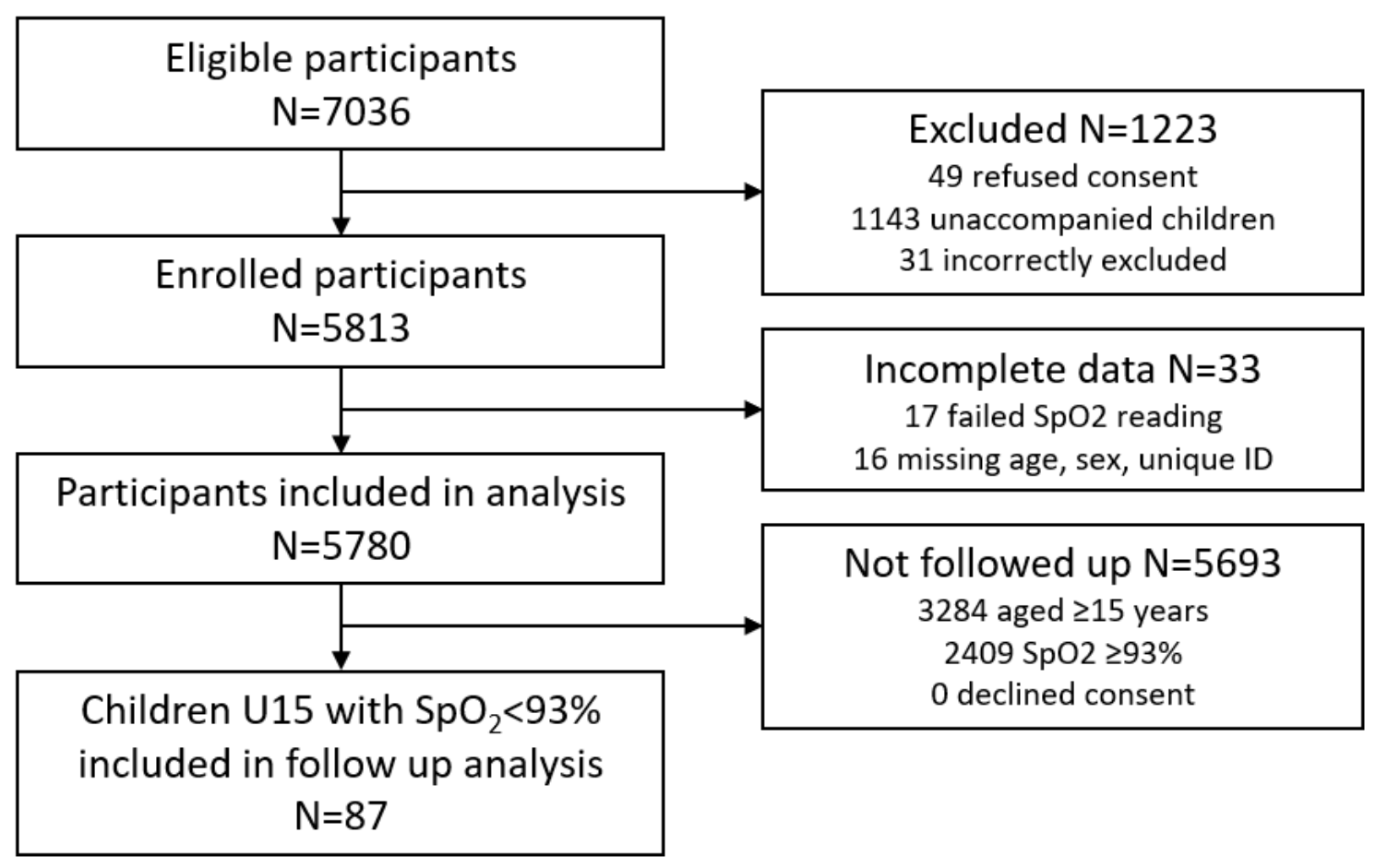


medRxiv preprint doi: https://doi.org/10.1101/2021.12.13.21267753; this version posted December 14, 2021. The copyright holder for this preprint (which was not certified by peer review) is the author/funder, who has granted medRxiv a license to display the preprint in perpetuity.

It is made available under a CC-BY-ND 4.0 International license .

Pulse oximetry in Ugandan primary care

\section{Figure 2 Prevalence of severe or moderate hypoxaemia (SpO2<94\%) among acutely unwell children and adolescents presenting to HCIII facilities in Uganda, Feb-Apr 2021, by presenting complaint and age}

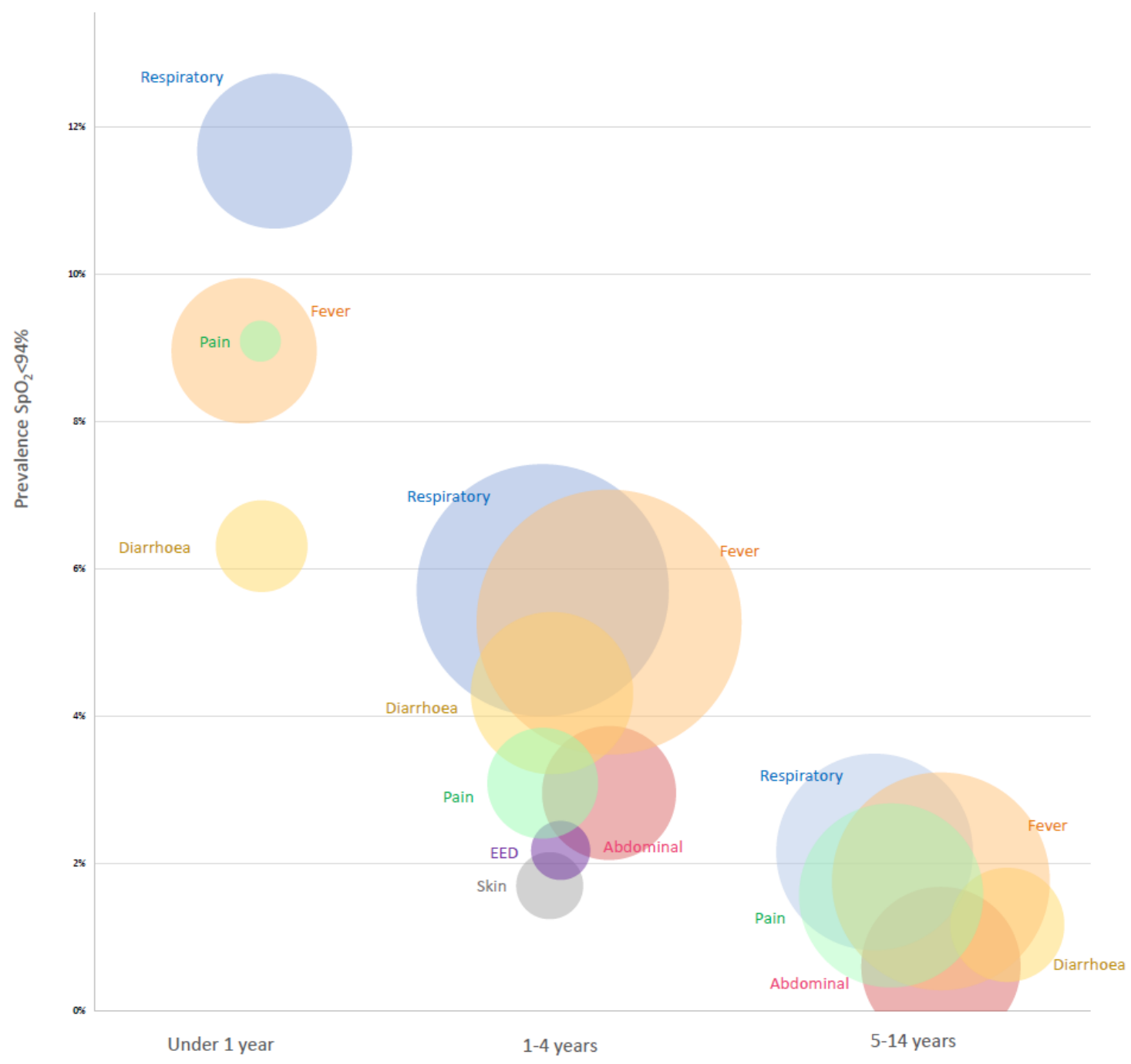

Notes: Size of bubble represents the number of participants, with hypoxaemia prevalence increasing up the y axis. Categories are not mutually exclusive, with many participants reporting multiple presenting complaints, however the bubble overlap is not necessarily proportional to actual presenting complaint overlap. Presenting complaint categories with less than 5 cases were excluded. 
medRxiv preprint doi: https://doi.org/10.1101/2021.12.13.21267753; this version posted December 14, 2021. The copyright holder for this preprint (which was not certified by peer review) is the author/funder, who has granted medRxiv a license to display the preprint in perpetuity.

It is made available under a CC-BY-ND 4.0 International license .

Pulse oximetry in Ugandan primary care

Figure 3 Flow chart showing referral, facility attendance, and day 7 outcomes for 87 children with hypoxaemia SpO2<93\%

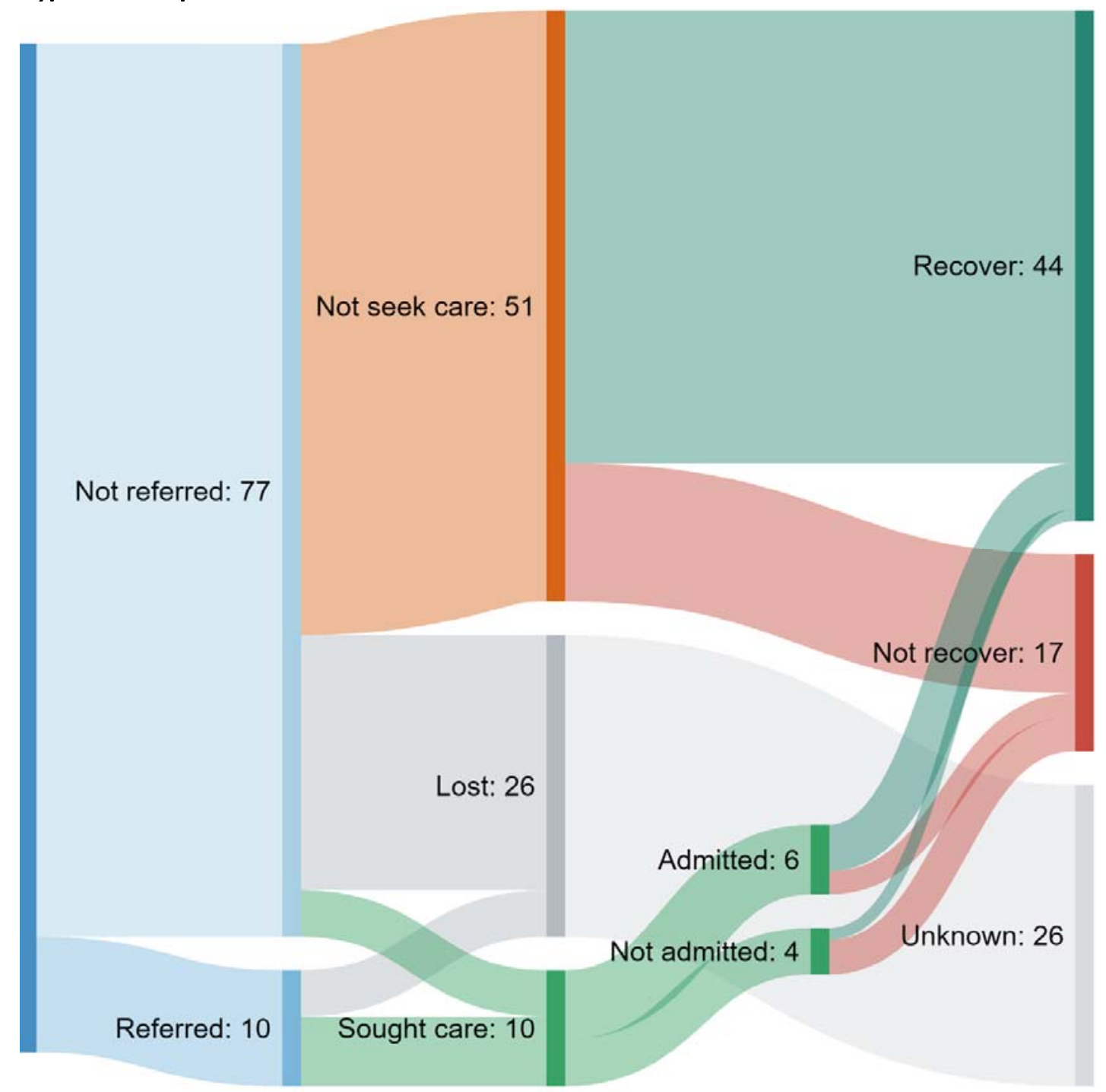


medRxiv preprint doi: https://doi.org/10.1101/2021.12.13.21267753; this version posted December 14, 2021. The copyright holder for this preprint (which was not certified by peer review) is the author/funder, who has granted medRxiv a license to display the preprint in perpetuity.

It is made available under a CC-BY-ND 4.0 International license .

Pulse oximetry in Ugandan primary care

\section{References}

1. Graham H, Bakare AA, Ayede Al, et al. Hypoxaemia in hospitalised children and neonates: $A$ prospective cohort study in Nigerian secondary-level hospitals. EClinicalMedicine 2019;16:51-63. doi: 10.1016/j.eclinm.2019.10.009 [published Online First: 2019/12/14]

2. Lazzerini M, Sonego M, Pellegrin MC. Hypoxaemia as a Mortality Risk Factor in Acute Lower Respiratory Infections in Children in Low and Middle-Income Countries: Systematic Review and Meta-Analysis. PLOS ONE 2015;10(9):e0136166. doi: 10.1371/journal.pone.0136166

3. Subhi R, Adamson $M$, Campbell $H$, et al. The prevalence of hypoxaemia among ill children in developing countries: a systematic review. Lancet Infect Dis 2009;9:219-27. doi: 10.1016/S1473-3099(09)70071-4

4. Foran M, Ahn R, Novik J, et al. Prevalence of undiagnosed hypoxemia in adults and children in an under-resourced district hospital in Zambia. International Journal of Emergency Medicine 2010;3:351-56. doi: 10.1007/s12245-010-0241-5

5. Duke T, Subhi R, Peel D, et al. Pulse oximetry: technology to reduce child mortality in developing countries. Ann Trop Paediatr 2009;29:165-75. doi: 10.1179/027249309X12467994190011

6. WHO. Interagency list of priority medical devices for essential interventions for reproductive, maternal, newborn and child health. Geneva, Switzerland: World Health Organization (WHO), UNICEF, UNFPA, 2016.

7. WHO. Priority medical devices list for the COVID-19 response and associated technical specifications: Interim guidance 19 November 2020. Geneva, Switzerland: World Health Organization (WHO), 2020.

8. Zhang L, Mendoza-Sassi R, Santos JCH, et al. Accuracy of symptoms and signs in predicting hypoxaemia among young children with acute respiratory infection: a meta-analysis [Review article]. The International Journal of Tuberculosis and Lung Disease 2011;15:317-25.

9. WHO. Integrated Management of Childhood Illness - Chart Booklet. Geneva: World Health Organization (WHO), 2014.

10. McCollum E, King C, Colbourn T, et al. Pulse oximetry in paediatric primary care in low-income and middle-income countries. Lancet Resp 2019;7:1001-02. doi:

https://doi.org/10.1016/S2213-2600(19)30358-3

11. Tesfaye SH, Gebeyehu Y, Loha E, et al. Pulse oximeter with integrated management of childhood illness for diagnosis of severe childhood pneumonia at rural health institutions in Southern Ethiopia: results from a cluster-randomised controlled trial. BMJ Open 2020;10(6):e036814. doi: 10.1136/bmjopen-2020-036814 [published Online First: 2020/06/23]

12. Graham HR, Olojede $O E, B a k a r e ~ A A$, et al. Measuring oxygen access: lessons from health facility assessments in Lagos, Nigeria. BMJ global health 2021;6(8) doi: 10.1136/bmjgh-2021006069

13. Simkovich SM, Underhill L, Kirby MA, et al. Resources and Geographical Access to Care for Severe Pediatric Pneumonia in Four Resource-Limited Settings. Americal Journal of Respiratory and Critical Care Medicine 2021

14. McCollum ED, Makwenda C, Colbourn T, et al. Pulse oximetry for children with pneumonia treated as outpatients in rural Malawi. Bull World Health Organ 2016(94):893-902. doi: 10.2471/BLT.16.173401

15. King C, Boyd N, Walker I, et al. Opportunities and barriers in paediatric pulse oximetry for pneumonia in low-resource clinical settings: a qualitative evaluation from Malawi and Bangladesh. BMJ Open 2018;8:e019177. doi: 10.1136/

16. Feinmann J. How covid-19 revealed the scandal of medical oxygen supplies worldwide. Bmj 2021;373:n1166. doi: 10.1136/bmj.n1166 [published Online First: 2021/05/14]

17. Graham HR, Bagayana SM, Bakare AA, et al. Improving Hospital Oxygen Systems for COVID-19 in Low-Resource Settings: Lessons From the Field. Global Health: Science and Practice 2020;8(4):1-5. doi: https://doi.org/10.9745/GHSP-D-20-00224 
medRxiv preprint doi: https://doi.org/10.1101/2021.12.13.21267753; this version posted December 14, 2021. The copyright holder for this preprint (which was not certified by peer review) is the author/funder, who has granted medRxiv a license to display the preprint in perpetuity.

It is made available under a CC-BY-ND 4.0 International license .

Pulse oximetry in Ugandan primary care

18. Nakkazi E. Oxygen supplies and COVID-19 mortality in Africa. The Lancet Respiratory Medicine 2021 doi: 10.1016/s2213-2600(21)00087-4

19. Stein F, Perry M, Banda G, et al. Oxygen provision to fight COVID-19 in sub-Saharan Africa. BMJ global health 2020;5(6) doi: 10.1136/bmjgh-2020-002786 [published Online First: 2020/06/14]

20. Usher AD. Medical oxygen crisis: a belated COVID-19 response. The Lancet 2021;397(10277):86869. doi: 10.1016/s0140-6736(21)00561-4

21. Westfall A. A fundamental and sustainable response to COVID-19: improving local oxygen systems. 30 April 2020 ed. UNICEF: UNICEF, 2020.

22. WHO. Oxygen sources and distribution for COVID-19 treatment centres. Geneva: World Health Organization (WHO), 2020.

23. Chandna A, Osborn J, Bassat Q, et al. Anticipating the future: prognostic tools as a complementary strategy to improve care for patients with febrile illnesses in resourcelimited settings. BMJ Glob Health 2021;6(7) doi: 10.1136/bmjgh-2021-006057 [published Online First: 2021/08/01]

24. Graham HR, Bakare AA, Gray A, et al. Adoption of paediatric and neonatal pulse oximetry by 12 hospitals in Nigeria: a mixed-methods realist evaluation. BMJ global health 2018;3:e000812. doi: 10.1136/bmjgh-2018-000812

25. Enoch AJ, English M, Shepperd S. Does pulse oximeter use impact health outcomes? A systematic review. Arch Dis Child 2016;101(8):694-700. doi: 10.1136/archdischild-2015-309638

26. UN IGME. United National Inter-Agency Group for Child Mortality Estimation (UN IGME): United Nations Inter-agency Group for Child Mortality Estimation (UN IGME), 2019.

27. MOH-Uganda. National Scale up of Medical Oxygen Implementation Plan. Kampala, Uganda: The Republic of Uganda Ministry of Health, 2018.

28. MOH-Uganda. Uganda Clinical Guidelines 2016: National Guidelines for Management of Common Conditions. Kampala: Republic of Uganda Ministry of Health, 2016.

29. WHO. Handbook: IMCl integrated management of childhood illness. Geneva, Switzerland: World Health Organization 2005.

30. (UBOS) UBoS, ICF. Uganda Demographic and Health Survey 2016: Key Indicators Report. Kampala, Uganda: UBOS and ICF, 2017.

31. O'Dempsey T, Todd J. Chest infections in African children. Bmj 1993;306(6888):1342.

32. WHO. Oxygen therapy for children. Geneva: World Health Organization, 2016.

33. WHO. Pocket Book of Hospital care for children: guidelines for the management of common childhood illnesses. 2nd ed. Geneva: World Health Organization 2013.

34. Graham HR, Bakare AA, Ayede Al, et al. Hypoxaemia in hospitalised children and neonates: a prospective cohort study in Nigerian secondary-level hospitals. EClinicalMedicine 2019 doi: https://doi.org/10.1016/i.eclinm.2019.10.009

35. Raman S, Prince NJ, Hoskote A, et al. Admission PaO2 and Mortality in Critically III Children: A Cohort Study and Systematic Review. Pediatr Crit Care Med 2016;17(10):e444-e50. doi: 10.1097/PCC.0000000000000905 [published Online First: 2016/08/11]

36. Conlon C, Nicholson E, Rodriguez-Martin B, et al. Factors influencing general practitioners decisions to refer Paediatric patients to the emergency department: a systematic review and narrative synthesis. BMC Fam Pract 2020;21(1):210. doi: 10.1186/s12875-020-01277-9 [published Online First: 2020/10/18]

37. McCollum ED, King C, Deula R, et al. Pulse oximetry implementation with rural frontline and community health workers during three years of child pneumonia care in two central Malawi districts: a prospective observational study, 2016.

38. Starr N, Rebollo D, Asemu YM, et al. Pulse oximetry in low-resource settings during the COVID-19 pandemic. Lancet Glob Health 2020;8(9):e1121-e22. doi: 10.1016/s2214-109x(20)30287-4 
medRxiv preprint doi: https://doi.org/10.1101/2021.12.13.21267753; this version posted December 14, 2021. The copyright holder for this preprint (which was not certified by peer review) is the author/funder, who has granted medRxiv a license to display the preprint in perpetuity.

Pulse oximetry in Ugandan primary care

It is made available under a CC-BY-ND 4.0 International license.

39. Luks AM, Swenson ER. Pulse Oximetry for Monitoring Patients with COVID-19 at Home. Potential Pitfalls and Practical Guidance. Ann Am Thorac Soc 2020;17(9):1040-46. doi: 10.1513/AnnalsATS.202005-418FR [published Online First: 2020/06/11]

40. Greenhalgh $T$, Knight $M$, Inda-Kim $M$, et al. Remote management of covid-19 using home pulse oximetry and virtual ward support. Bmj 2021;372:n677. doi: 10.1136/bmj.n677 [published Online First: 2021/03/27]

41. WHO. Clinical management of severe acute respiratory infection when novel coronavirus (2019$\mathrm{nCoV}$ ) infection is suspected. 2020

42. Subhi R, Smith K, Duke T. When should oxygen be given to children at high altitude? A systematic review to define altitude-specific hypoxaemia. Arch Dis Child 2009;94(1):6-10. doi: http://dx.doi.org/10.1136/adc.2008.138362

43. Ayieko P, English M. In children aged 2-59 months with pneumonia, which clinical signs best predict hypoxaemia? Journal of Tropical Pediatrics 2006;52:307-10. doi: 10.1093/tropej/fml036

44. Usen S, Weber M. Clinical signs of hypoxaemia in children with acute lower respiratory infection: Indicators of oxygen therapy. International Journal of Tuberculosis and Lung Disease 2001;5(6):505-10.

45. von der Weid L, Gehri M, Camara B, et al. Clinical signs of hypoxaemia in children aged 2 months to 5 years with acute respiratory distress in Switzerland and Senegal. Paediatr Int Child Health 2018;38(2):113-20. doi: 10.1080/20469047.2017.1390828 [published Online First: 2017/11/07]

46. McCollum ED, King C, Colbourn T, et al. Pulse oximetry in paediatric primary care in low-income and middle-income countries. The Lancet Respiratory Medicine 2019 doi: 10.1016/s22132600(19)30358-3

47. Kigozi SP, Kigozi RN, Sebuguzi CM, et al. Spatial-temporal patterns of malaria incidence in Uganda using HMIS data from 2015 to 2019. BMC Public Health 2020;20(1):1913. doi: 10.1186/s12889-020-10007-w [published Online First: 2020/12/16]

48. Baker K, Petzold M, Mucunguzi A, et al. Performance of five pulse oximeters to detect hypoxaemia as an indicator of severe illness in children under five by frontline health workers in low resource settings - A prospective, multicentre, single-blinded, trial in Cambodia, Ethiopia, South Sudan, and Uganda. EClinicalMedicine 2021;38 doi: 10.1016/j.eclinm.2021.101040

49. Lipnick MS, Feiner JR, Au P, et al. The Accuracy of 6 Inexpensive Pulse Oximeters Not Cleared by the Food and Drug Administration: The Possible Global Public Health Implications. Anesth Analg 2016;123(2):338-45. doi: 10.1213/ANE.0000000000001300

50. Modi AM, Kiourkas RD, Li J, et al. Reliability of Smartphone Pulse Oximetry in Subjects at Risk for Hypoxemia. Respir Care 2021;66(3):384-90. doi: 10.4187/respcare.07670 [published Online First: 2020/10/08]

51. Okunlola O, Lipnick MS, Batchelder P, et al. Pulse Oximeter Performance, Racial Inequity, and the Work Ahead. Respir Care 2021 doi: 10.4187/respcare.09795 [published Online First: 2021/11/14] 